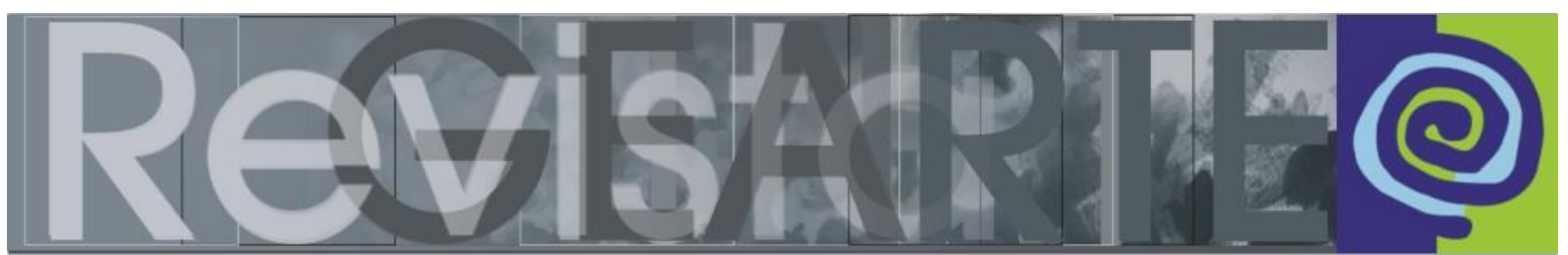

ISSN 2357-9854 | e-ISSN 2596-3198 (online)

\title{
O que não pode ser escrito merece ser vivido'?
}

\author{
Betania Libanio Dantas de Araujo \\ (Universidade Federal de São Paulo - Unifesp, Guarulhos/SP, Brasil)
}

\begin{abstract}
RESUMO - $O$ que não pode ser escrito merece ser vivido? - $O$ artigo analisa a importância da Arte na formação do pedagogo, tendo como referência a docência da autora no curso de Pedagogia da Universidade Federal de São Paulo, campus Guarulhos, entre 2011 e 2020. As disciplinas Fundamentos Teórico-práticos do Ensino da Arte e eletivas, as Práticas Pedagógicas Programadas, a Residência Pedagógica e as pesquisas orientadas são momentos sistemáticos desse encontro, que, utilizando o Laboratório de Arte (Labart) como atelier coletivo, promoveu vivências nos fazeres e saberes da arte. Em relação à produção, o resgate das produções individuais e coletivas, a elaboração dos memoriais e a criação do Museu Virtual do Desenho da Criança contribuem para diversos aspectos da formação dos alunos, cujas experiências com as Artes Visuais podem ser sintetizadas em uma espiral poética, na qual interagem a razão intuitiva, a imaginação criadora e intersubjetividade.
\end{abstract}

PALAVRAS-CHAVE

Ensino da Arte. Pedagogia. Práxis artística. Processo criativo. Memorial.

ABSTRACT - What cannot be written deserves to be lived? - The article analyzes the importance of Art in the formation of pedagogues, having as reference the author's teaching in the Pedagogy course at the Federal University of São Paulo, Guarulhos campus, between 2011 and 2020. The Subject Theoretical-Practical Foundations of Art Teaching and electives, the Programmed Pedagogical Practices, the Pedagogical Residency and the guided researches are systematic moments of this meeting, which, using the Art Laboratory (Labart) as a collective studio, promoted experiences in the doings and knowledge of art. Regarding production, the recovery of individual and collective productions, the elaboration of memorials and the creation of the Museu Virtual do Desenho da Criança contribute to various aspects of the education of students, whose experiences with the Visual Arts can be synthesized in a poetic spiral, in which intuitive reason, creative imagination and intersubjectivity interact.

KEYWORDS

Art Education. Pedagogy. Artistic praxis. Creative process. Memorial.

RESUMEN - ¿Lo que no se puede escribir merece ser vivido? - El artículo analiza la importancia del Arte en la formación de los pedagogos, teniendo como referencia la docencia de la autora en el curso de Pedagogía de la Universidad Federal de São Paulo, campus Guarulhos, entre 2011 y 2020. La asignatura Fundamentos Teórico-Prácticos de la Enseñanza del Arte y optativas, las Prácticas Pedagógicas Programadas, la Residencia Pedagógica y las investigaciones orientadas son los momentos sistemáticos de este encuentro, que, utilizando el Laboratorio de Arte (Labart) como estudio colectivo, promovió experiencias en el hacer y conocimiento del arte. En cuanto a la producción, la recuperación de las producciones individuales y colectivas, la elaboración de memoriales y la creación del Museu Virtual do Desenho da Criança contribuyen a varios aspectos de la formación de los estudiantes, cuyas experiencias con las Artes Visuales pueden sintetizarse en una espiral poética, en la que la razón intuitiva, la imaginación creativa y la intersubjetividad interactúan.

\section{PALABRAS CLAVE}

Educación Artística. Pedagogía. Praxis artística. Proceso creativo. Memorial. 


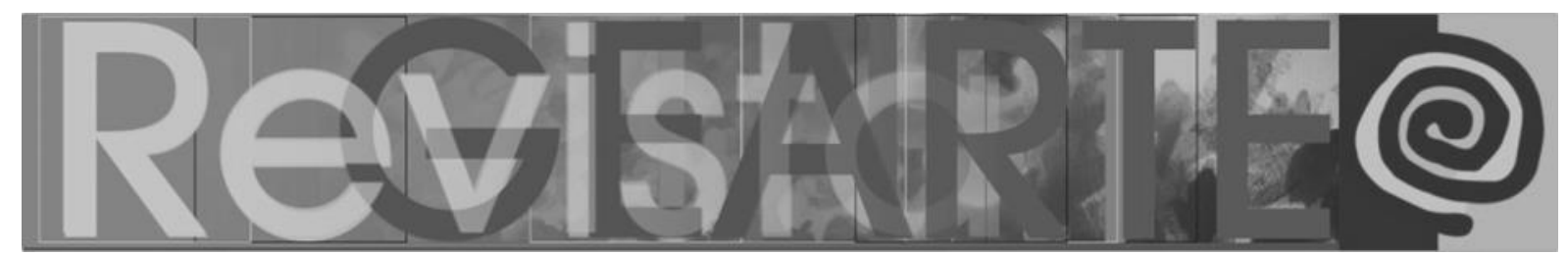

A criação é o contrário da alienação.

(GARAUDY, 1967, p. 65)

Figura 1 - Haikaidrinhos
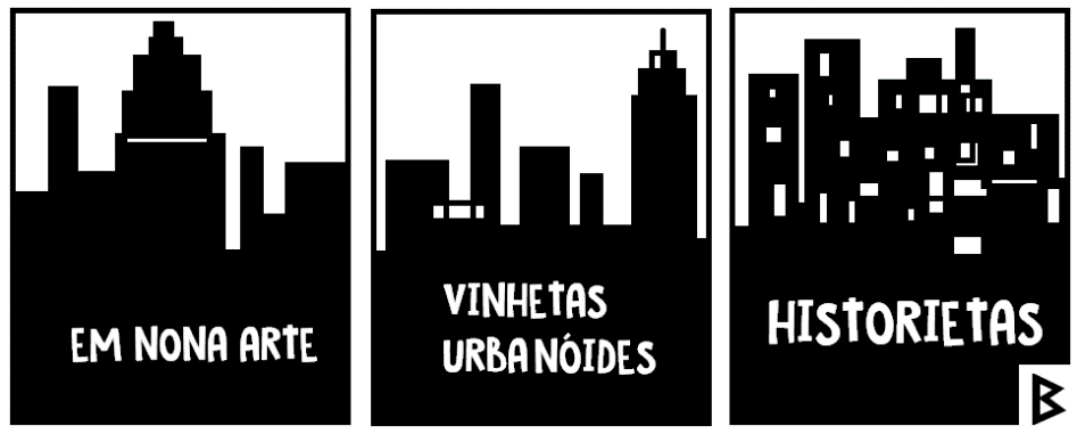

Fonte: Acervo de Betania Araujo (2018).

Para abordar a importância das artes no curso de Pedagogia da Universidade Federal de São Paulo - Campus Guarulhos - descrevo inicialmente o contexto da universidade e posteriormente a experiência.

Quando a universidade ainda não existia, movimentos fervilhavam na zona leste, e em São Paulo, desde os anos 1970. Lutavam pelo acesso à educação de qualidade para os trabalhadores e suas famílias, almejando a construção de universidades públicas que se espalhassem pelas cidades (LIBANIO, 2002).

Essa utopia começou a ser concretizada a partir do ano de 2003, com a reestruturação e a expansão das universidades e dos institutos federais pelo país, com o REUNI, com a criação do Enem, bem como com a criação das cotas de ingresso e permanência. Em 2006, a Universidade Federal de São Paulo (UNIFESP) inaugura um campus dedicado às Ciências Humanas em Guarulhos, com os cursos de Pedagogia, Ciências Sociais, Filosofia, História, Letras e História da Arte. É importante apontar que a Escola Paulista de Medicina - EPM transformou-se em Universidade Federal de São Paulo em 1994.

A universidade localiza-se no bairro Jardim Nova Cidade. Dista, aproximadamente, $16 \mathrm{~km}$ do centro de Guarulhos, pertence ao distrito Pimentas, com sessenta bairros, sendo o Jardim Nova Cidade um dos cinco bairros mais populosos. Localizado no centro do distrito, juntamente com Parque Jurema, é o centro comercial dos Pimentas. Os dois bairros são separados pela Avenida 


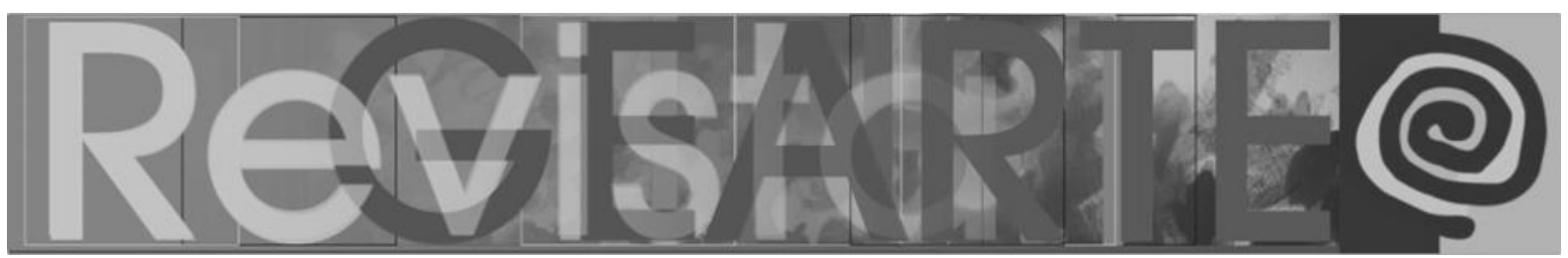

Presidente Juscelino Kubitschek de Oliveira. Os colonizadores nomearam os indígenas como Guarus, originando o nome da cidade, no entanto eram Maromomis.

O curso de Pedagogia da Universidade Federal, campus Guarulhos, possui um desenho curricular cujas áreas de conhecimento, ao longo do curso, apresentam-se em diferentes formatos além das disciplinas obrigatórias. O vínculo do curso com a municipalidade se viabiliza através de um acordo de cooperação da UNIFESP Guarulhos com a escola pública da cidade. Diferentemente de um estágio formal, todos os docentes do curso - os professores preceptores atualmente orientam a residência pedagógica. $O$ projeto de residência pedagógica ${ }^{2}$ da UNIFESP foi criado em 2006.

É um movimento mais orgânico, em que a universidade se apresenta não como detentora de conhecimentos, mas como parceira para construir conjuntamente experiências e saberes em um diálogo constante. É uma ação com a escola e não para a escola. Na escolha da preposição, a escola faz-se propositiva.

$\mathrm{Na}$ paleta de cores desta "pintura", cada cor ora se mistura, ora diz propriamente, ora é matizada e sempre dialoga e, no diálogo, assume nova qualidade perceptiva. Escultoricamente, tanto a escola, quanto a universidade, nos talha e modela, por vezes, de maneira aditiva, por outras, subtrativa.

Temos, no curso, o eixo dos fundamentos teórico-práticos e neste, o núcleo das expressividades artísticas, constituindo: a unidade curricular Fundamentos Teórico-práticos do Ensino das Artes, ministrada nas áreas de Artes Visuais e Música e a unidade curricular Fundamentos Teórico-práticos da Cultura Corporal na escola, ministrada na área corpo em movimento.

A resolução que institui as diretrizes curriculares para o curso de Pedagogia, obviamente, aponta para os conhecimentos a serem mediados pelo futuro pedagogo em perspectiva transdisciplinar. Ao longo do curso a transversalidade 


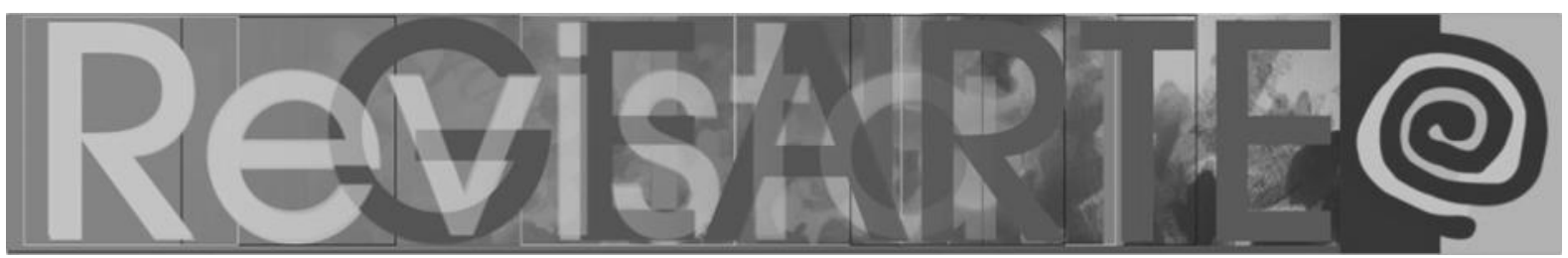

advém do trajeto constituído pelo estudante em situações de ensino, pesquisa e extensão.

\title{
As Artes Visuais: ver melhor e transformar
}

\begin{abstract}
O mero contato com as obras-primas não é suficiente. Pessoas em demasia visitam museus e colecionam livros de arte sem conseguir acesso à mesma. A capacidade inata para entender através dos olhos está adormecida e deve ser despertada. E a melhor maneira é manusear lápis, pincéis, escalpelos e talvez câmaras. Mas também nesse âmbito, maus hábitos e conceitos errôneos costumam bloquear o caminho daquele que trabalha sem orientação. (ARNHEIM, 2006, p. 13)
\end{abstract}

A área de Artes Visuais busca despertar o olhar e o fazer artísticos. Por não ser uma disciplina voltada para o curso de Artes, exige igual complexidade, mas em outro campo. Construir uma disciplina no curso de Pedagogia é uma experiência singular porque, no encontro de ambas as áreas - Arte e Pedagogia -, a fusão conceitual produz novos nexos gerando aprendizagens significativas. Para potencializar a ação criadora as experiências precisam ser diversificadas, de naturezas diferentes e transformando materiais. A arte visual é fonte de novas formas de inventar e imaginar o mundo integrando na personalidade os sentidos, antes dispersos e desconexos.

No $7^{0}$ termo, os estudantes cursam a Unidade Curricular Fundamentos Teórico-práticos do Ensino da Arte. A área de Artes Visuais oferta, além da disciplina obrigatória, disciplinas eletivas, Práticas Pedagógicas Programadas (PPP's) e Residência Pedagógica.

Em artes visuais, intenciono que os estudantes retomem e/ou deem continuidade ao seu percurso criador, conheçam a história do ensino da arte no Brasil em seus documentos oficiais, reflitam sobre as memórias artísticas na vida e na escola, experimentem os fazeres artísticos das artes visuais (bidimensionais e tridimensionais) com alguns materiais das Belas Artes e outros reciclados/construídos, conheçam a gramática visual da imagem e do desenho da criança e percebam a mudança da natureza expressiva das garatujas aos simbolismos. Os ateliês em movimento, assim como o moderno e o 


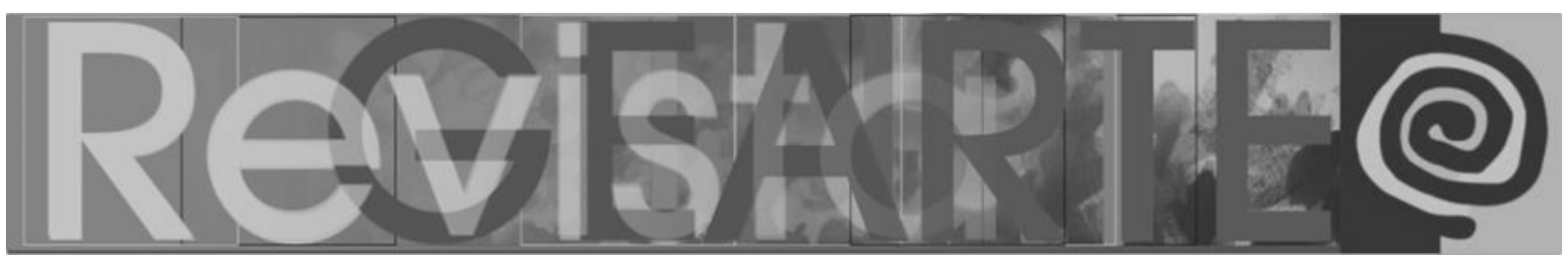

contemporâneo nas artes visuais, são experiências muito pertinentes na disciplina, porque podem qualificar as ações dos futuros profissionais. É a oportunidade de refazer o seu percurso (o desenvolvimento da capacidade inventiva dos estudantes/educadores) de contato com as artes por meio de experiências e vivências no fazer, no contextualizar e no refletir, a fim de tornar consciente os processos de ensino-aprendizagem.

Vale destacar que o futuro pedagogo atuará em diferentes níveis, modalidades de ensino e gestão escolar, então, sua formação no campo das artes Ihe acompanhará em sua trajetória profissional, ou seja, é uma pedagogia da familiarização cultural (PORCHER, 1982, p. 44), em que não podem ocorrer atalhos, é preciso tempo de maturação. A preparação dos pedagogos sensibilizaria esteticamente o tempo certo da infância em uma Pedagogia da criatividade: "[...] ou a criatividade é o objeto dessa pedagogia, ou ela é o seu fundamento, quando não seu agente" (PORCHER, 1982, p. 33).

Uma sondagem que dialoga com leituras, fruições e fazeres da arte antecipa um currículo mais vivo, que parta das necessidades de formação, que inspire e seja inspirado. A primeira aula é o momento para conhecer os desejos e as necessidades dos educandos.

Os estudantes desejam dar continuidade aos seus desenhos, porém, a escola não possibilitou isso, negando-Ihes um direito. O desenho expressivo é recomeçado. Aprender a olhar e puxar o fio da linha é o propósito, porque desenhar é assim, feito gato curioso que empurra o novelo e congela o movimento para descobrir se o novelo está vivo. A linha ainda está viva como em nossa infância? É deixar o novelo rolar, encontrar o desenho inesperado e olhar novamente. Vamos voltar a brincar nas artes, contrariando a frase que se ouvia na infância: brinque enquanto pode.

Nessa perspectiva artística, é possível encontrar sombras no chão em dia de lua cheia ou surpreender-se com um botão que desabrocha no campus em 


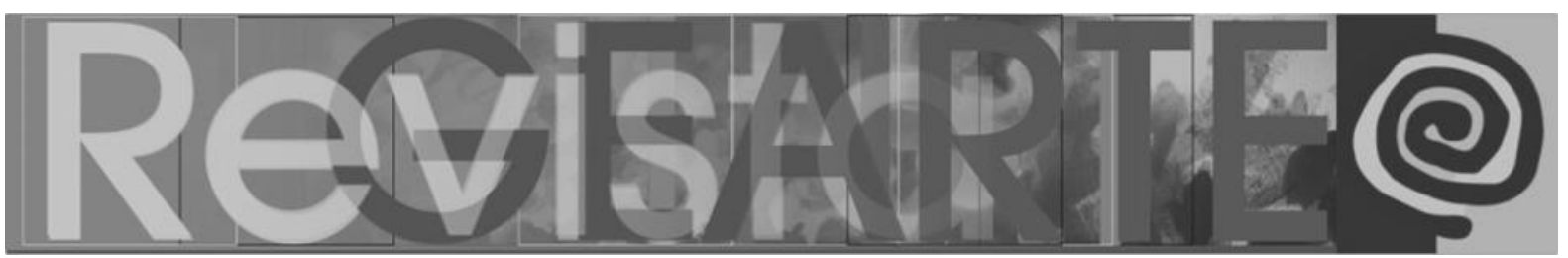

exercícios haikaístas, sentar no último andar do prédio da universidade para ver um pôr do sol espetacular, descobrir cenas da janela do ônibus em olhar espremido, reinventar a volta para casa em corpos cansados e, ainda, fotografar tardes coloridas de outono em dias de quarentena com reduzida poluição. Vida e arte são unas!

Figura 2 - Tarde pela janela

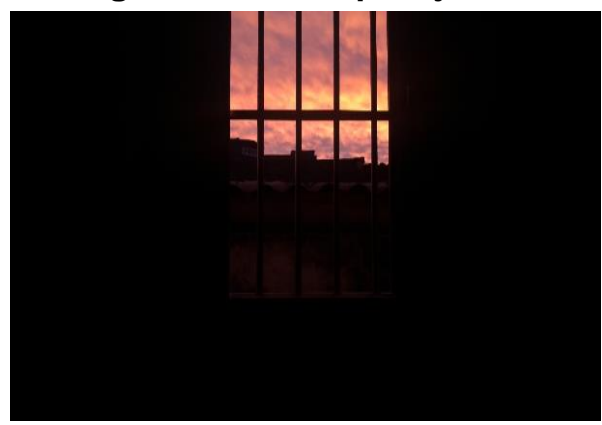

Fonte: Foto de Gustavo Xavier Gisolfi (2020).

As cartografias poéticas em nossa universidade ressignificam o nosso deslocamento, juntos ou apartados. Já foi performance de frente ao Graffiteratura ${ }^{3}$.

Com o objetivo de envolver a comunidade acadêmica na escolha, o grafite de $600 \mathrm{~m}^{2}$, O Auto da barca do inferno, resultou de uma chamada pública, sendo uma das três pinturas mais votadas pela comunidade para a criação de uma identidade visual ao campus. A inauguração do grafite ocorreu com a participação dos artistas Grego, Beto Silva e Frenesi. A partir de 2016, ocorreram doze performances neste grafite enquanto exercícios cartográficos.

Figura 3 - Graffiteratura Auto da barca do inferno

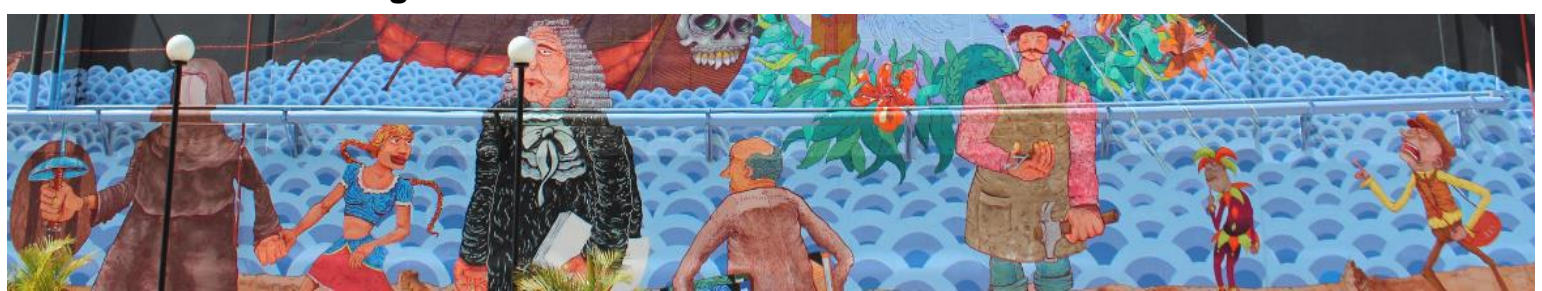

Fonte: Unifesp Guarulhos (2016).

Os estudantes aventuram-se em novas descobertas. Por exemplo, a performance na luta contra o feminicídio O que me marca pode te marcar também, da estudante/artista Aguida Aguiar, e a instalação de sapatos vermelhos pelo ARAUJO, Betania Libanio Dantas de. O que não pode ser escrito merece ser vivido? 532 Revista GEARTE, Porto Alegre, v. 8, n. 2, p. 527-553, maio/ago. 2021.

Disponível em: http://seer.ufrgs.br/gearte 


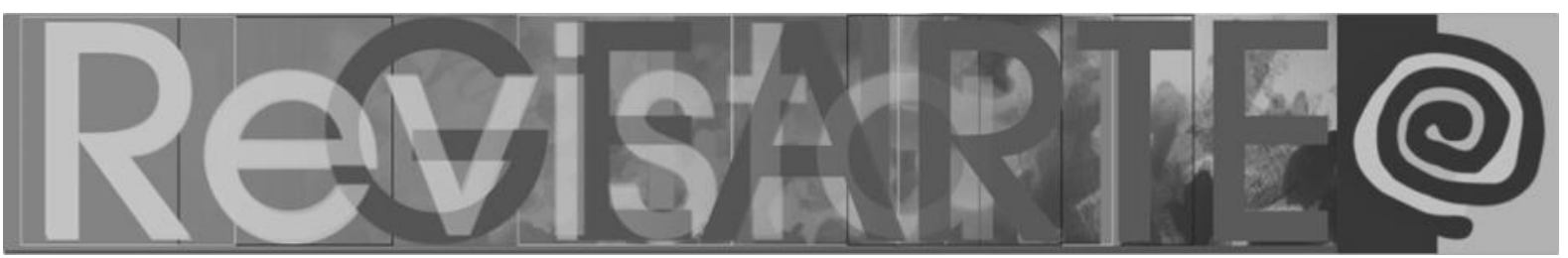

campus, inspirados na intervenção que a artista plástica Elina Chauvet realizou no México após a sua irmã ser assassinada pelo companheiro; também, o projeto coordenado por Daniela Finco, da área de Educação Infantil e infâncias, voltado ao estudo do gênero, preconceito e violência. Realizamos uma ação extensionista das artes.

Figura 4 - Performance $O$ que me marca pode te marcar também de Aguida Aguiar. Descrição: fio de aço que enrola e desenrola enquanto a mulher se desloca calmamente pelo espaço. $O$ seu rosto é coberto por um ornamento de flores e plantas de trigo que a impedem de ver

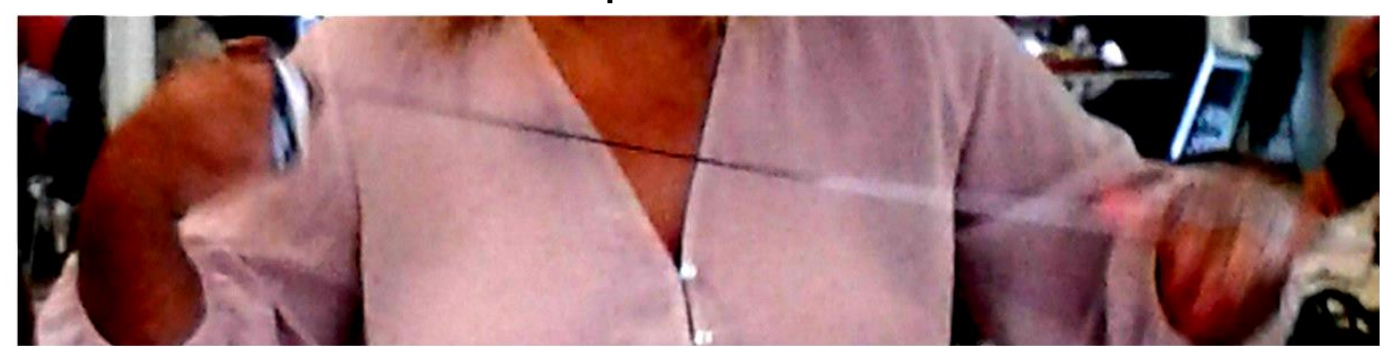

Fonte: Acervo de Betania Araujo (2018).

A investigação de que a arte está em tudo estabelece nova camada de compreensão ao encontrá-la inerente à vida: uma vez que alguém desenhou o projeto que originou tudo o que me avizinha. Ainda consigo ter inspiração na natureza que nasce por pura teimosia na cidade de pedra. Ponto e linha sobre plano fazem sentido nas imagens da escolha pessoal.

Figura 5 - Foto haikaísta. Vista interna da estação ferroviária São Miguel, um dos trajetos realizados pela comunidade acadêmica

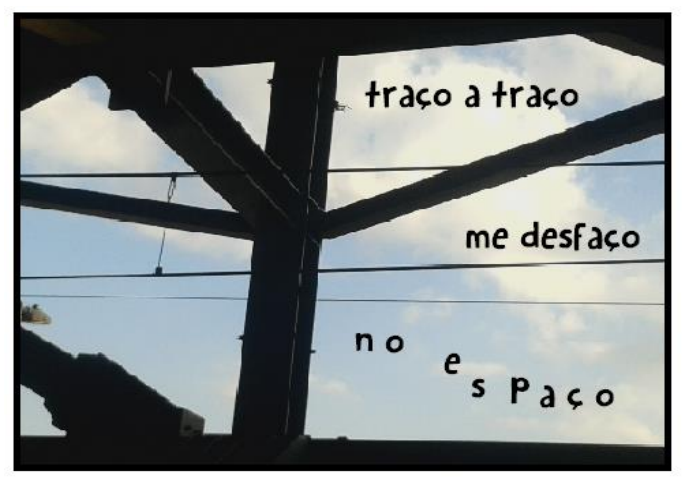

Fonte: Acerco de Betania Araujo (2013).

Por considerar que procedimento não é técnica, conhecer a manipulação de cada material poderá transformar-se em um modo de fazer pessoal. Instigar o 


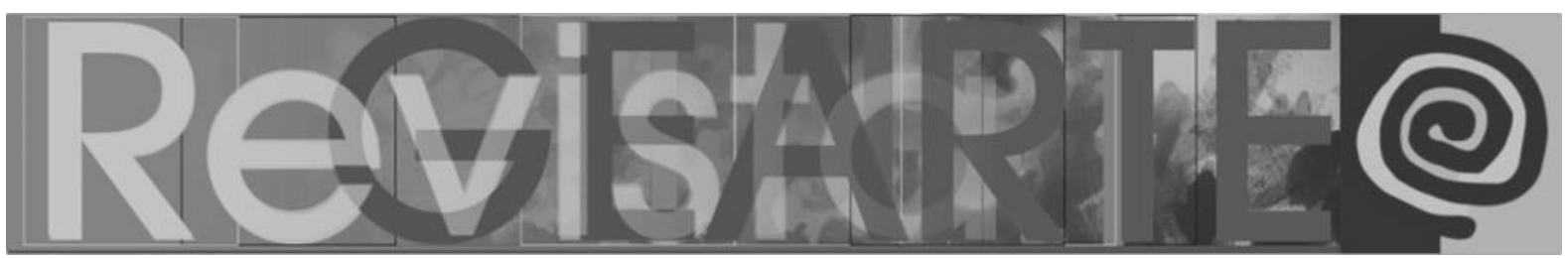

estudante para criar ferramentas e aventurar-se nos experimentos e nos registros auxilia na futura criação dos seus próprios procedimentos, afinando uma técnica pessoal. É "[...] perceber intuitivamente possibilidades de transformar dados comuns em uma nova criação que transcende a matéria-prima”, segundo Edwards (1984, p. 15).

As engenhocas das artes visuais são produções de geringonças que fazem arte gerando surpresa: braço pintor mecânico movido à injetora, escultura de voo, pintura na reação química, manivela para pintura abstrata entre outras ferramentas; pois como expõe Porcher (1982, p. 15) "[...] é preciso instrumentos necessários" para a autoexpressão.

A relação estabelecida com cada material é qualificada pelos meus intentos enquanto docente. Tomo as palavras de Edwards (1984, p.16) para apresentar os intuitos de minha ação: acordar a "[...] capacidade adormecida e pouco explorada em decorrência de nossa cultura verbal, tecnológica e nosso sistema educacional" proporcionando meios que potencializem a criatividade "[...] tendo acesso à capacidade inventiva, intuitiva e imaginativa a um nível consciente". Mudar a maneira de olhar as coisas para que as palavras deixem "[...] de ter um lugar na consciência" perdendo "[...] a percepção da passagem do tempo", materializando tudo o que fizer sentido.

Perceber que o desenho não é um ato mágico, mas, sim, que possui tensão, trabalho e, segundo Vigotski, seleção de aspectos reais para novos combinados de criação pessoal, o que envolve memória e imaginação, processo de interação com o meio (VYGOTSKY, 2014, p. 6). Um percurso marcado por bastante aventura, em que suportes, materiais e proposições nascem das artes visuais, mas dialogam e interagem com as outras áreas de conhecimento que compõem o campo formativo do pedagogo. A objetividade da ação e a subjetividade da pesquisa nos fornecem as necessidades para pensarmos nas pontes cognitivas de Ausubel. 


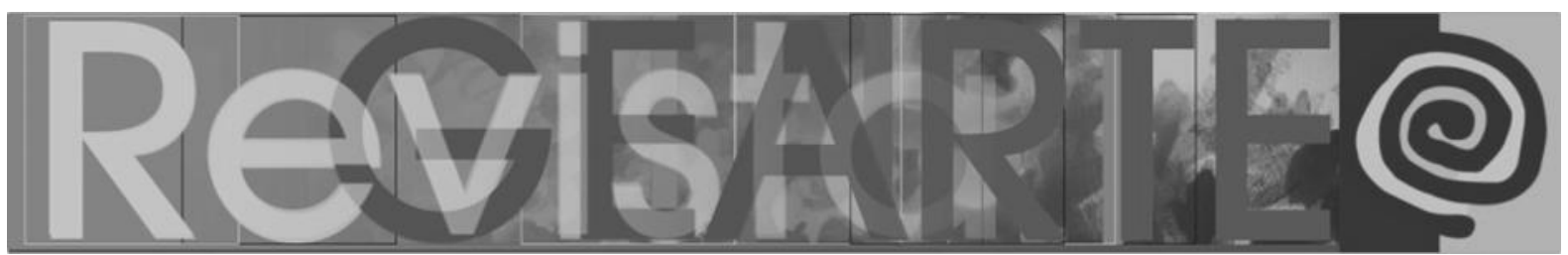

Com a LDB 9394/96, a grande maioria dos alunos teve duas aulas de arte no Ensino Fundamental II e apenas uma no $1^{\circ}$ ano do Ensino Médio. Estudar a legislação é olhar para o seu passado, entender politicamente o que ocorreu e lutar pela presença da arte na escola.

\title{
As materialidades das artes visuais: pensar com as mãos
}

É comum as pessoas entenderem a arte e seus fazeres como um dom especial daquele que a produz, o artista. Para além desse senso comum ou visão idealista, o fazer artístico envolve todo um processo de trabalho e mediação cultural. Iniciando-se por uma ideia, um desejo ou necessidade de expressão e, do seu planejamento à obra finalizada, muitas etapas são percorridas, ações experimentadas, planos alterados, materiais e ferramentas constantemente aprimorados. Percurso longo, muitas vezes penoso, o processo criativo chega a desafiar inúmeras vezes o sujeito, que transforma (e é transformado por) matéria em objeto cultural.

Resgatamos uma bela passagem do professor Alfredo Bosi (2000):

\begin{abstract}
Parece ser próprio do animal simbólico valer-se de uma só parte do seu organismo para exercer funções diversíssimas. A mão sirva de exemplo. A mão arranca da terra a raiz e a erva, colhe da árvore o fruto, descascao, leva-o à boca. A mão puxa e empurra, junta e espalha, arrocha e afrouxa, contrai e distende, enrola e desenrola; roça, toca, apalpa, acaricia, belisca, unha, aperta, esbofeteia, esmurra; depois, massageia o músculo dolorido. A mão tateia com as pontas dos dedos, apalpa e calca com a polpa, raspa, arranha, escarva, escarifica e escarafuncha com as unhas. Com o nó dos dedos, bate. A mão abre a ferida e a pensa. Eriça o pêlo e o alisa. Entrança e destrança o cabelo. Enruga e desenruga o papel e o pano. Unge e esconjura, asperge e exorcisa. [...] Apanha com gestos o eu, o tu, o ele; o aqui, o aí; o hoje, o ontem, o amanhã; o pouco, o muito, o mais ou menos; o um, o dois, o três, os números até dez e os seus múltiplos e quebrados. O não, o nunca, o nada. É voz do mudo, é voz do surdo, é leitura do cego. Faz levantar a voz, amaina o vozerio, impõe silêncio. Saúda o amigo balançando leve ao lado da cabeça e, no mesmo aceno, estira o braço e diz adeus, urge e manda parar. Traz ao mundo a criança, esgana o inimigo. [...] A mão, portadora do sagrado. As mãos postas oram, palma contra palma ou entrançando os dedos ... (BOSI, 2000, p. 67)
\end{abstract}




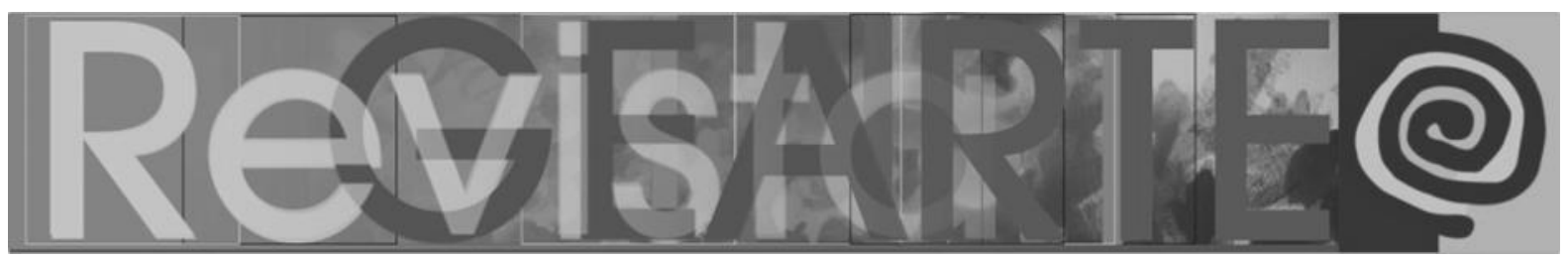

A materialidade do mundo e as leis de seu desenvolvimento apontam para a unidade deste em movimento. O ser humano modifica a natureza, dominando-a como resultado do trabalho.

A pesquisa em artes visuais é a luta com a matéria, o desejo de controlá-la e transformá-la, como bem destacou poeticamente Bosi. Por esse motivo, a arte é o caminho da transformação e, por que não afirmar, da autotransformação, da descoberta de suas qualidades e de seus limites. Envolve observação, pesquisa, análise, e a elaboração de diversos planos para solucionar um problema, sendo este exercício a preparação de um ser humano que procura novas soluções aos problemas que coloca a si e, por reconhecê-los, é capaz de solucioná-los.

A arte possui um fluxo contínuo de entrar em si e dar forma; desenvolve-se um respeito ao material, dando o tempo necessário para conhecê-lo, em sua essência, nas forças vitais do universo, como expansão, contração, volume, espaço, movimento, ritmo e equilíbrio.

$\mathrm{Na}$ retomada do desejo e do impulso artístico, preparo o reencontro dos estudantes com o material que lhes fez sofrer, que caracterizou a sua exposição, a tristeza em não conseguir captar o mundo, o abandono dos clichês, estereótipos, a preparação do olhar e o reencontro com a matéria. É um novo reencontro com a arte. A tentativa de ter uma experiência feliz e que exige empenho. $O$ impulso artístico fora esquecido neste mundo das letras e números, da educação disciplinar corpórea jesuítica (do não tocar), da repressão das experiências corporais. É a retomada dos entorpecidos arquétipos da criação.

Nesta nova tentativa de realizar este encontro, é preciso guiar os olhares para os espaços de arte que ainda não eram considerados, é preciso acordar e acolher as flores internas que tanto dialogam com a ancestralidade por nós desconhecida, com os caminhos traçados em outrora, com os gestos do nosso país e de nossa família. Quem compõe em arte compreende alguns destes propósitos. 


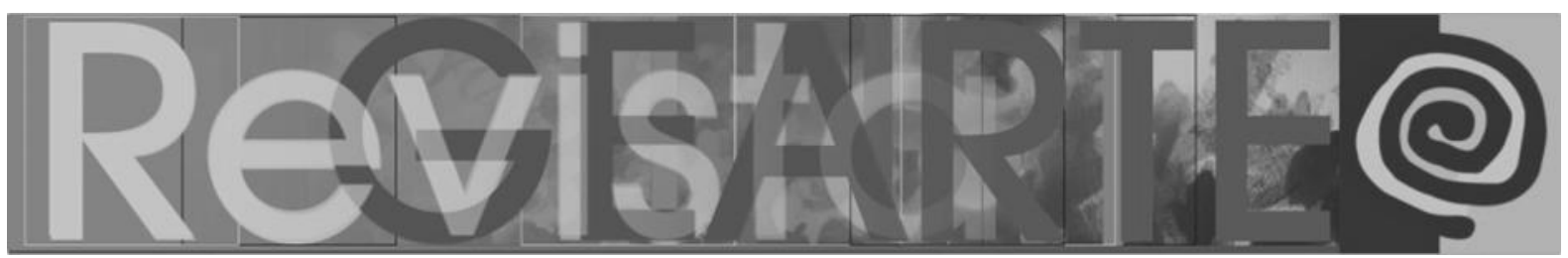

Grande parte dos estudantes relatam as exposições, os medos, os modelos e a falta de experiência nas escolas privadas e públicas por onde estudaram. Essa reaproximação precisa ser cuidadosa e um dos caminhos é instrumentalizar, com algumas orientações que agucem o olhar, ativando as sensorialidades na descoberta do seu mundo interno, na escolha de suas imagens. Com essa descoberta, que alimenta o percurso criador individual $e$ a sua identidade/identificação, podemos pinçar criações de artistas, para aumentar esse mergulho verticalizado.

\section{As forças imaginantes}

As forças imaginantes da nossa mente desenvolvem-se em duas linhas bastante diferentes. Umas encontram seu impulso na novidade; divertemse com o pitoresco, com a variedade, com o acontecimento inesperado. A imaginação que elas vivificam tem sempre uma primavera a descrever. $\mathrm{Na}$ natureza, longe de nós, já vivas, elas produzem flores. As outras forças imaginantes escavam o fundo do ser; querem encontrar no ser ao mesmo tempo, o primitivo e o eterno. (...) Na natureza, em nós e fora de nós, elas produzem germes; germes em que a forma está encravada numa substância, em que a forma é interna. (BACHELARD, 1998, p. 1)

Por um lado, são brincantes e por outro carregam significados internos. É a "imaginação íntima" das "forças vegetantes e materiais" que Bachelard (1998, p. 2) dedica à obra: encontrar na "imagem que se mostra, a imagem que se oculta", seguindo a raiz imaginante. $\mathrm{Na}$ "vegetação obscura", há flores com textura e aroma. A imaginação trabalha "onde vai a alegria" em suas formas, cores, variedades, metamorfoses, profundidades e volumes, encontrando a sua superfície. É necessário que uma causa sentimental, uma causa do coração se torne uma causa formal para que a obra tenha variedade do verbo... "A vista the dá nome, mas a mão as conhece" (BACHELARD, 1998, p.2). 


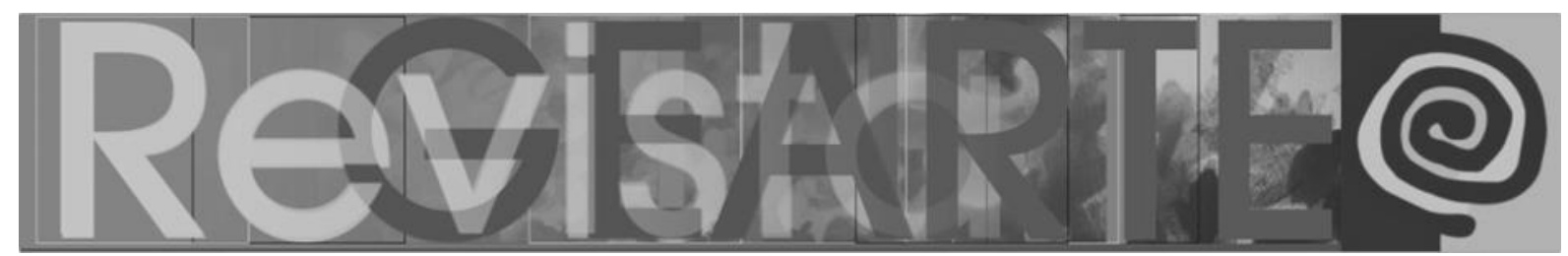

Figura 6 - Papelotagem realizada em grupo após estudos de desenhos sobre animais. Há um processo anterior que dá confiança na linha gráfica individual para a escolha do desenho pelo grupo, observo que escolhem animais que mais o desafiam nesta aventura da tridimensionalidade

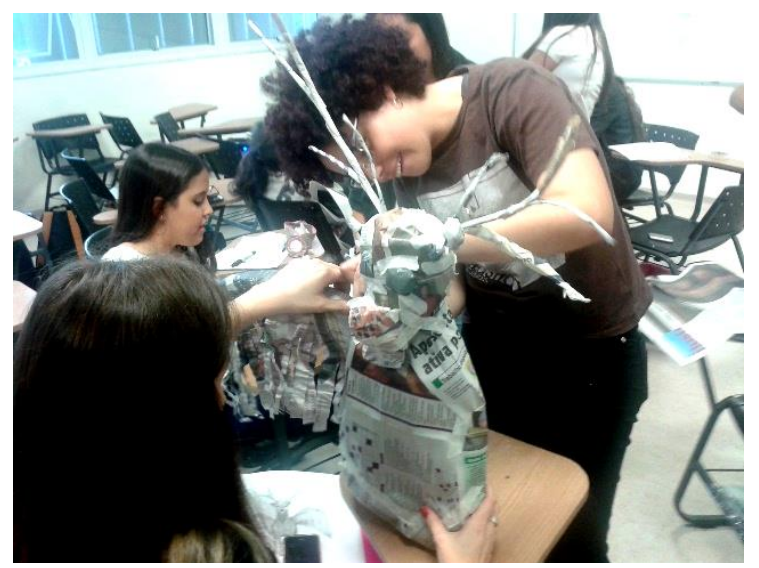

Fonte: Acervo de Betania Araujo (2013).

Para a aprendizagem ocorrer é preciso densidade, lentidão e germinação (BACHELARD, 1998, p.2). Os estudantes relatam a continuidade de seus estudos em casa e como é importante a solidão intelectual nesta transformação das materialidades. Estaria aí a contribuição da arte para a pedagogia "[...] uma coisa é certa, em todo caso: o devaneio na criança é um devaneio materialista. A criança é um materialista nato. Seus primeiros sonhos são os sonhos das substâncias orgânicas" (BACHELARD, 1998, p.9).

O ambiente acolhedor, portanto, não hostil, potencializa o que já existe no sentimento de criação e descoberta do mundo real. É preciso proporcionar a confiança ao estudante. Sentir-se livre, considerando que todos possuem expressão artística e que não há proibições ou perseguições, é a base para darmos continuidade às pesquisas.

A produção que ocorre no primeiro dia de aula fornece o conhecimento prévio para a inclusão de novas necessidades ao currículo previsto, ou seja, a recondução da ação educativa. Já a avaliação formativa tem a função de identificar aprendizagens e não-aprendizagens sobrevém, diariamente, das produções individuais, no seminário e/ou ficha dissertativa, no memorial, no portfólio. 


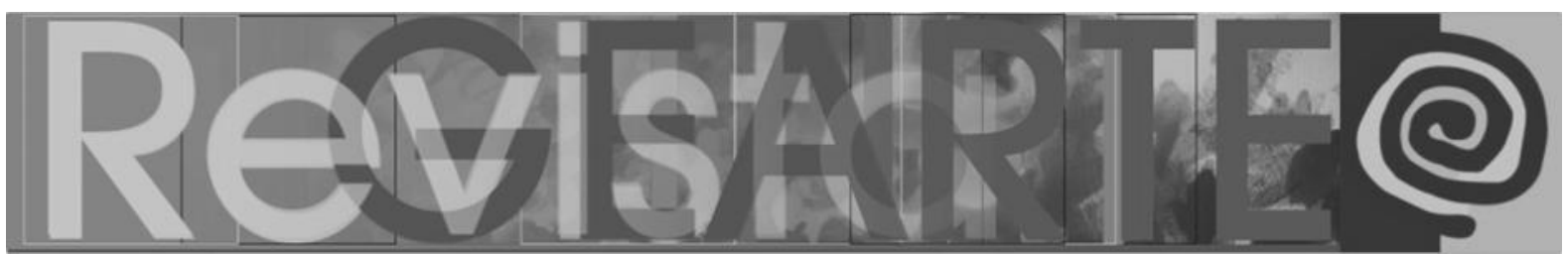

A uma só linha é o exercício de retomada da linha contínua, não mais o tracejado da escrita, pensando no gesto, no ritmo e na cor. Essa percepção fica mais clara com Miró, Picasso e Kandinsky. Conversamos sobre composição e diversidade na unidade.

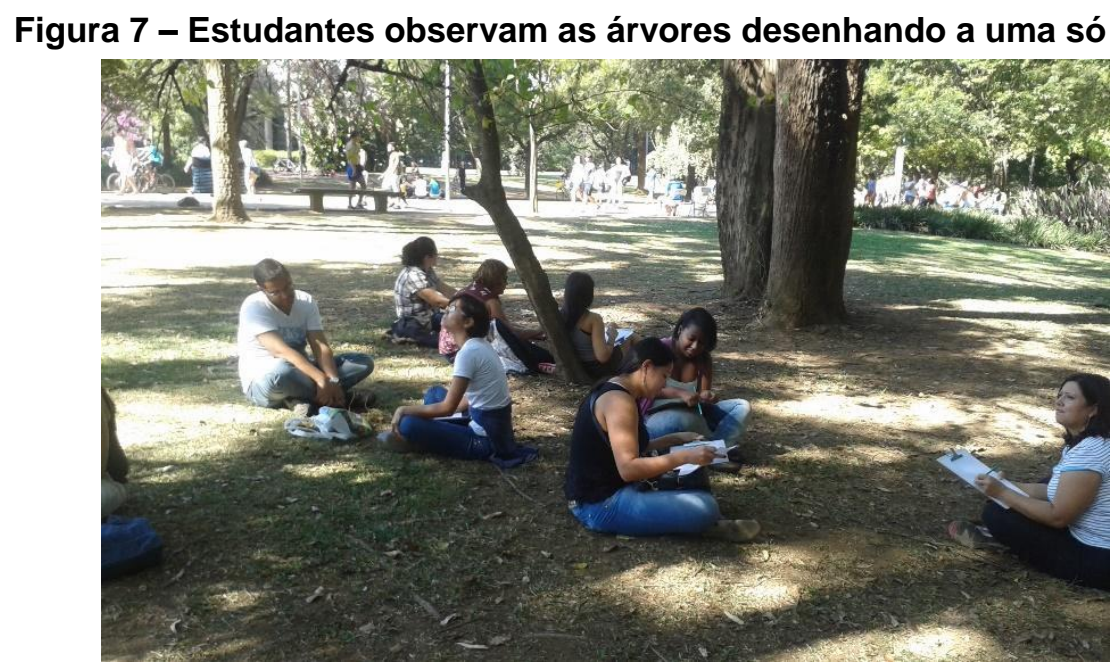

Fonte: Acervo de Betania Araujo (2013).

Ainda hoje me lembro de que, ainda menina, eu costumava dizer a mim mesma que, para desenhar algum objeto, era preciso antes fazer certa "coisa". Que "coisa" era essa eu jamais defini, mas sabia que tinha de olhar fixamente, durante algum tempo, o objeto que eu queria desenhar até que essa "coisa" acontecesse. (EDWARDS, 1984, p. 8)

Documentar estilos, interesses, inovações e experimentos que possibilitem leituras comparadas: o portfólio, ou porta-folha, é a memória do seu trajeto. Parte de propostas ocorridas na universidade $e$ acolhe as aprendizagens $e$ reverberações experimentadas pelo estudante. Essa coleção conta a história dos seus esforços (VILLAS BOAS, 2004), seu progresso e desempenho, a participação do estudante na seleção de conteúdo e a autorreflexão. Pode ter uma seleção e trazer análise de tentativas.

Além do acompanhamento nas aulas, o portfólio recebe uma apreciação final do docente, que pode apontar a continuidade de sua pesquisa visual: onde investir mais, ideias sobre estudos do tema pessoal, amplitude e demonstração de maior intimidade com alguns materiais - esses são os processos formativos de avaliação que consideram o caminho individual percorrido. 


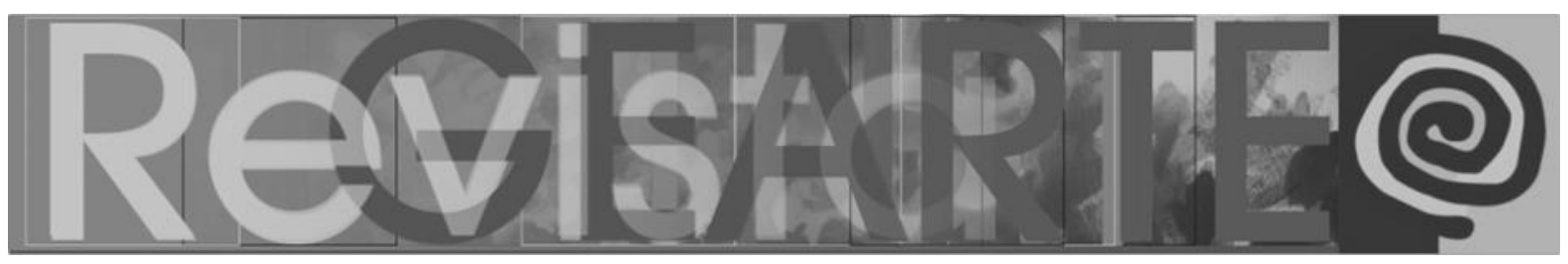

Em alguns momentos coloco a seguinte questão: onde parei? O que preciso para dar continuidade? Ao final, fecho com um feedback para as ações futuras. Ver a sua produção como algo contínuo, inspirado na longa trajetória dos artistas, como pesquisa, problema percebido, retomada, mudança de proposta, enfim, como a produção das visualidades, inspira as ações que tomamos na vida, dando maior flexibilidade às resoluções, tolerância à frustração e capacidade de superação de problemas. A observação cotidiana com o portfólio.

O laboratório de Artes (Labart) foi construído para acolher as produções das artes plásticas e das demais disciplinas que necessitam de bancadas e pias. É um espaço múltiplo que tem acolhido diversas experiências artísticas do campus, como ensaios de dramaturgia e bateria, múltiplas linguagens que necessitam de espaço ou bancadas. É significante o impacto de se ter um espaço para movimentos mais livres e integrados. Para nossa surpresa, algumas pesquisas passaram a refletir sobre o impacto muito positivo acerca das ações das artes plásticas e o próprio ambiente em si. No entanto, as turmas estão maiores e o mobiliário precisa ser ampliado.

RPG (role-playing game) no Labart jogo e educação foi uma parceria com a estudante Carol Motta, que foi a mestra, com o objetivo de realizar um estudo artístico mitológico dos personagens da cultura brasileira em aprendizagem de jogos educativos. Considero potente a multimodalidade da arte no RPG enquanto extensão com características que utilizo em aula.

A criação da cor poética é outro experimento de liberdade e pesquisa. Atualmente, com a quantidade de cores para parede e unhas, todos compreendem que uma paleta pode ter nomes poéticos, cores-objeto, tal como uma criança que certa vez criou um verde e deu-lhe o nome de grama em dia de chuva e ao cinza, intitulou tarde de trovão.

A liberdade de criação tonal envolve manipulação de cores, é possível conhecer alguns princípios/procedimentos para que o estudante viva a 


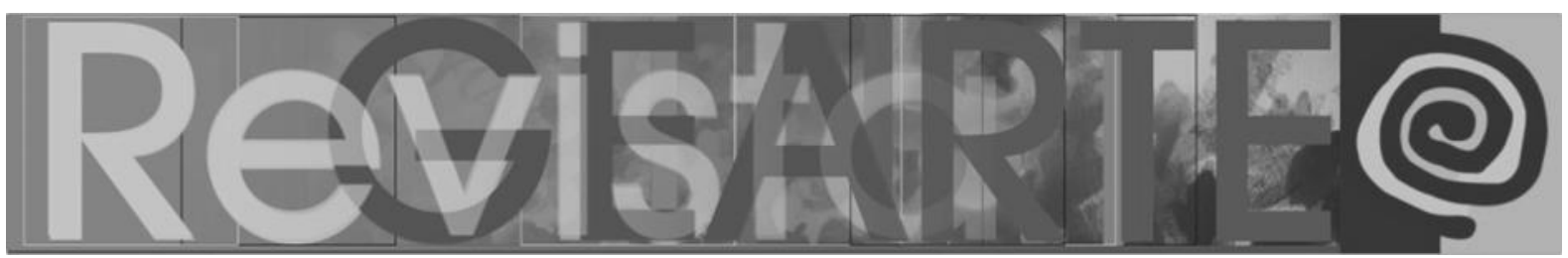

verticalidade proposta por Bachelard (1998, p.4), conduzindo o ser "[...] em tensão para um adiante, um mais adiante, um acima", de acréscimos à psique humana. A relação docente/discente é uma parte da formação, mas só se torna completa com "[...] o instante de solidão que o impulsiona num voo ascensional e fecundo, fazendo-o vivenciar a imaginação criadora, assegurando, assim, o verdadeiro crescimento espiritual" (BARBOSA; BULCÃO. 2004, p. 71).

Ao nos afastar da "[...] rotina monótona e repetitiva que nos impede de crescer", a imaginação criadora impulsiona "[...] voo ascencional de liberdade plena" (BACHELARD, 1998, p. 73), ocorre o surgimento do novo e do inesperado.

$\mathrm{Na}$ escola de arte Bauhaus ${ }^{4}$, o pedagogo, artista e estudioso de cores, Johannes Itten (1888-1967), descobriu que cada estudante montava uma paleta de cores que dialogava com valores tonais do seu corpo (pele, olhos, cabelo). Posteriormente, a californiana Suzanne Caygill montou as paletas sazonais primavera, verão, outono e inverno. Essa descoberta pode assegurar ao estudante a autoconfiança de suas escolhas tonais. $O$ trabalho da arte é proporcionar pesquisas voltadas à harmonia da relação entre cores e a criação de novos tons.

A construção de um catálogo tonal da turma é realizada anualmente. Além da criação da cor, a tomada do mundo por outros tons é outro exercício de liberdade e percepção ampliada, da cor em céu rosa esverdeado, multicor, contemplação solitária, um devaneio do silêncio.

Um objeto afetivo, escolhido pelo estudante que possua uma história, inspira o futuro memorial. As diversas camadas de conhecimento no objeto escolhido remetem ao modo como foi construído. A sua história no mundo (desenho e material empregado) e o contexto do estudante são formas de pensar as artes visuais de maneira criativa com estudantes que se apropriam de seus enredos.

O olho, tornado humano em suas ações cada vez mais complexas porque sociais, atribui sentidos mais profundos aos objetos (MARX, 2004). A arqueologia do objeto afetivo remete a um olhar para a cultura material de si, desenvolvendo 


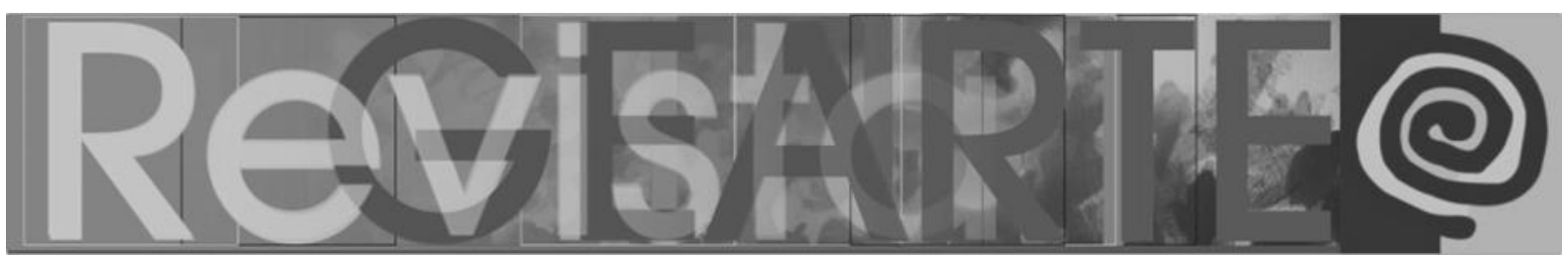

uma metodologia do olhar a partir do que se sabe ao ver e o que se sabe ao pesquisar. O exercício é de fazer a seleção do objeto que conte uma história significativa ao estudante, de maneira que o artefato escolhido evoque uma importante história para si.

Ao olhar para o objeto, busco preparar o olhar para: características físicas, construção, função, design, valor e origem. Há uma contextualização do objeto na história pessoal, um estudo de desenho e criação de um espaço ficcional para este artefato.

Ao trabalhar com memoriais ${ }^{5}$ de arte, surge a necessidade de orientar a nossa percepção, para que possamos revisitar o nosso passado, ressignificando a nossa história. A cada memória, com ou sem comemoração, agregamos novos sentidos enquanto nos aproximamos dos episódios humanos. O espaço do desenho: a educação do educador, de Ana Angelica Albano, é uma das obras que inspiram a escrita do memorial de artes. Dá continuidade à escrita sensível da memória, estabelece o desenho como linguagem da criança, ao passo que repensa esse espaço-tempo escolar para a recuperação do ser poético.

Estudar a história do ensino da arte é entender dois momentos bastante distintos: a nossa vida antes da escola e, depois, com a cultura escolar. A presença da arte em nossa vida e dentro da escola estabelece modos de fazer e conceber, portanto, estudar a história do ensino da arte é desconfiar desses modos, descobrir a sua origem e experimentar novas ações.

O memorial de arte dá sentido aos estudos sobre a história do ensino da arte no Brasil e ajuda a conhecermos modos criativos elaborados pelas infâncias nas apropriações de materiais naturais e sucatas no dia a dia. Não significa reviver, mas refazer-se, não é sonho, é trabalho (BOSI, 1994).

A ficha é uma contribuição de Celestin Freinet, sendo um contraponto ao que conhecemos como prova. A avaliação que ocorre ao final da disciplina dá o feedback ao estudante. Uma leitura comparada de suas produções ocorre na 


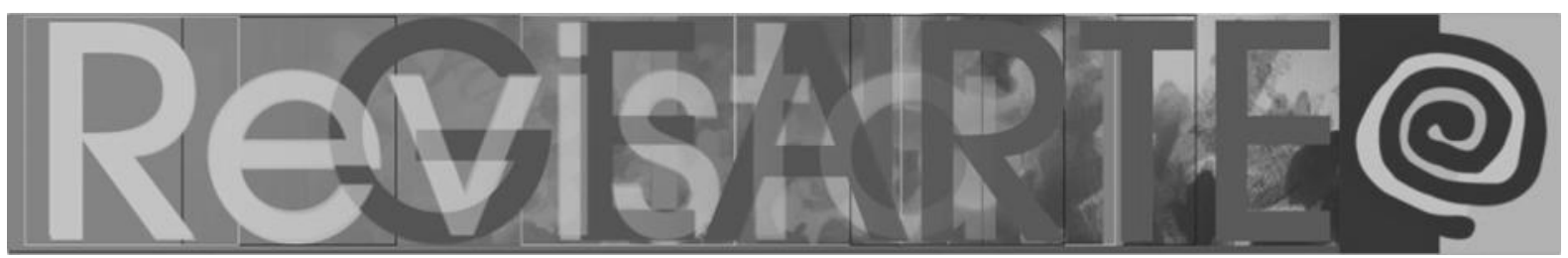

última aula, com previsões e perspectivas de continuidade. Há um diálogo entre o conhecimento prévio do estudante e as aprendizagens formativas da disciplina. A pergunta principal para mim é: o estudante tem descoberto os seus desejos, os temas que the geram alegria e investido em seu processo? Caso não tenha ocorrido essa mudança, quais foram os empecilhos?

As visitas semestrais aos museus, para conhecimento do acervo, asseguram o encontro com a ação educativa e a formação de um público especial, que são os futuros pedagogos no caminho de irradiação de novos públicos. A Bienal de Arte Contemporânea é nossa parceira, com visitas ao campus e visita dos estudantes à exposição. MAS, MAM, MAC, Pinacoteca, MLS, MUBE, Tomie Ohtake, Itaú Cultural, MuseuAfro Brasil, MASP, CCBB, Caixa Cultural são alguns dos museus de arte que proporcionaram um mergulho nas leituras de imagem e fruição artística. Não me esqueço da emoção de um estudante ao reconhecer que as obras brasileiras em exposição sempre o acompanharam em seus livros didáticos.

Figura 8 - Bate-papo em frente ao MAM: o encontro circular e a contextualização do espaço, da exposição e do jardim das esculturas

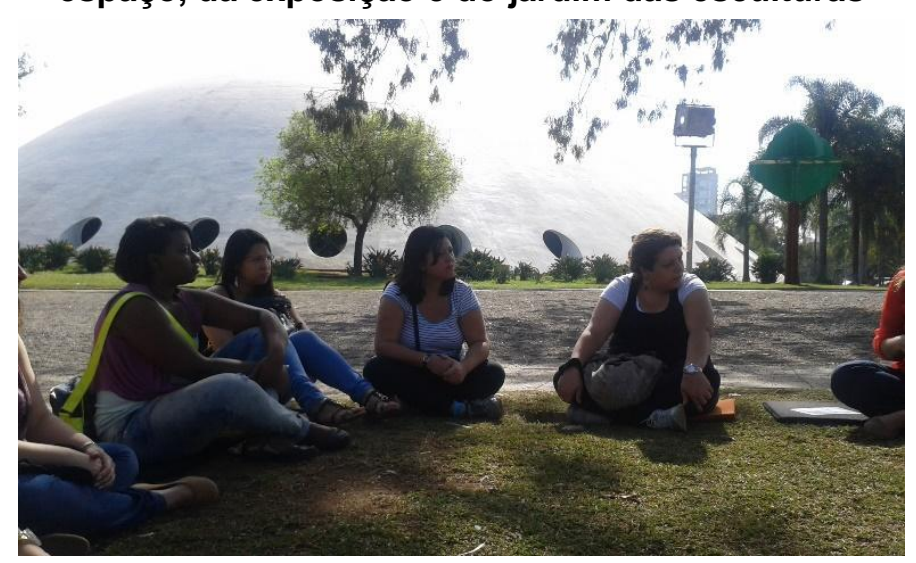

Fonte: Acervo de Betania Araujo (2014). 


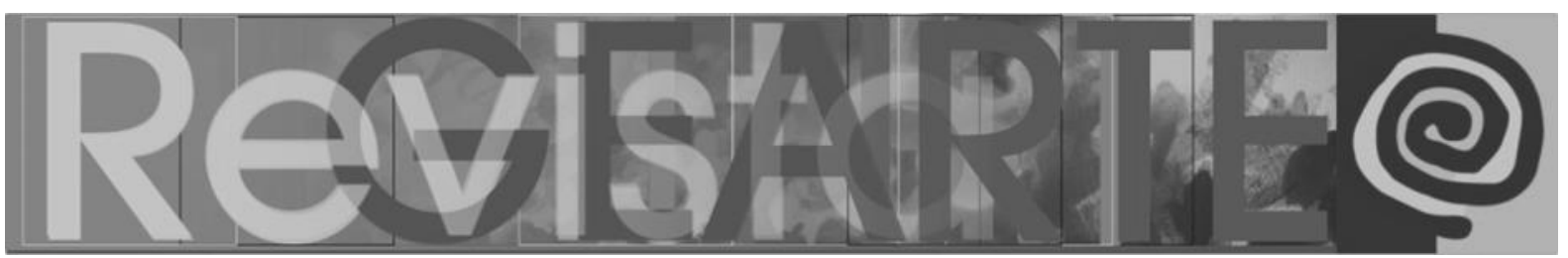

Figura 9 - CCBB - Eu caminho e descubro a obra

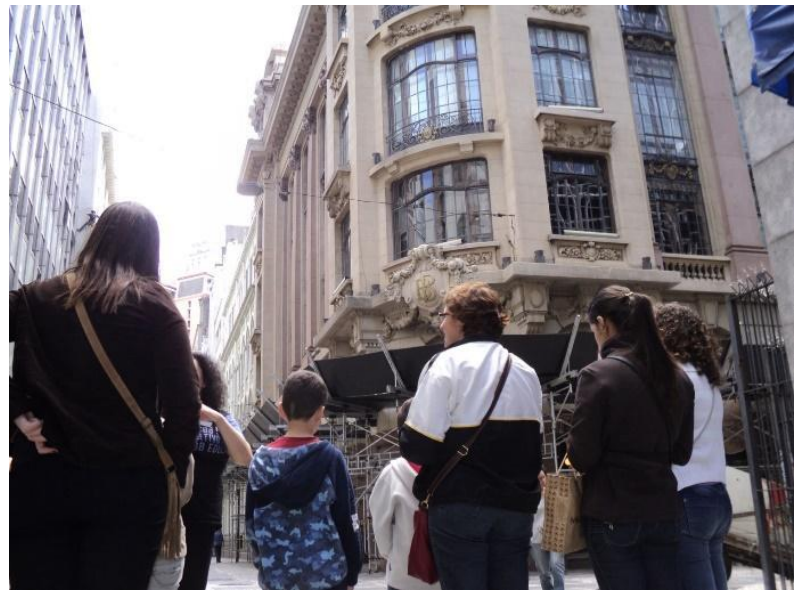

Fonte: Acervo de Betania Araujo (2013).

Os Trabalhos de Conclusão de Curso (TCC), orientados a partir de temas das artes visuais, sugerem que "[...] a mente funciona como um todo. Toda a percepção é também pensamento, todo o raciocínio é também intuição, toda observação é também invenção" (ARNHEIM, 2006, np)

Os campos fenomenais da arte são abertos [...] a produzir pesquisa, contudo, guardam consigo especificidades próprias vividas na dialética entre: sensível $\mathrm{x}$ inteligível; saber $\mathrm{x}$ fazer; singularidade $\mathrm{x}$ generalidade; verdade $\mathrm{x}$ exatidão" (TAVARES, 2016, p.68). Na ciência, o necessário discurso no "[...] âmbito abstrato dos fenômenos" constitui "[...] significação precisa”, privilegia a multiplicidade de significações (idem, p. 69).

Na orientação do TCC, tenho verificado uma grande procura dos estudantes em aprofundar estudos nas artes visuais em diálogo com a prática educativa. Como a minha preocupação é o processo criador, os estudantes trazem o tema de pesquisa com suas indagações iniciais e a minha função é orientá-los nos caminhos, além de ofertar materiais. Muito me surpreende a força e legitimidade das perguntas e hipóteses por eles construídas, ao que atribuo, por um lado, à maturidade desenvolvida no decorrer formativo do curso e, por outro, aos encontros com as artes visuais. 


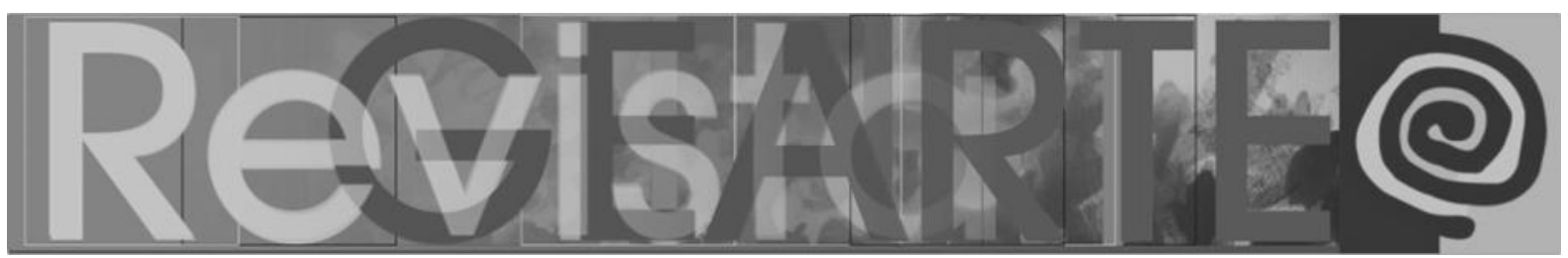

As trinta e oito pesquisas concluídas distribuem-se nas seguintes temáticas: onze pesquisas sobre arte na infância; cinco em arte e ciência; quatro sobre documentos oficiais do ensino da arte; três sobre grafite, atelier e cultura na escola, museus de arte, ação educativa e mobilidade cultural, teatro com crianças, humor e palhaçaria, EJA, memoriais de arte e formação de pedagogos, educação nãoformal, arte como educação significativa, o lúdico, arte contemporânea, desenhos pedagógicos, grafismos na infância, ações artísticas com bebês, criatividade, museu do desenho da criança, quadrinhos. Ocorreram outras duas pesquisas: teatro para bebês e palhaçaria, o humor na educação (que acolhi em função dos temas que pesquisei na pós-graduação), o bom humor enquanto exercício do pensamento divergente, o deslocamento do sentido primeiro no objeto enquanto reade-made e a constituição da imagem divertida para exercícios do clown reverberam nossos estudos da disciplina.

O conjunto das pesquisas realizadas pelos estudantes durante o trabalho de conclusão de curso indica que, além do rigor metodológico necessário, da intencionalidade e da busca de referenciais, o processo de pesquisa em arte acrescenta questões envolvendo intuição, acaso, descoberta e espanto. Busca-se o lógico, mas não se descarta o sensível. Concordamos com Zamboni (2012) que, ao destacar o grau de consciência necessária a uma pesquisa científica, não pretende "negar a existência da força intuitiva e sensível contida em qualquer processo de trabalho, seja em arte, seja em ciência" (ZAMBONI, 2012, p. 10).

Imagino que um conhecimento faça sentido quando contagia, como na passagem presente na pesquisa de Oliveira (2019): "[...] quero destacar que seu entusiasmo ao falar de arte me contagiou de tal forma que acabou por resultar nesta pesquisa".

As unidades curriculares eletivas de área, com carga horária de 75 horas, são cursadas pelos estudantes da Pedagogia, podendo ser abertas para Domínio Conexo e para os professores da rede municipal, e complementam a formação do estudante. Experimentos nas artes plásticas e processos de criação é uma eletiva 


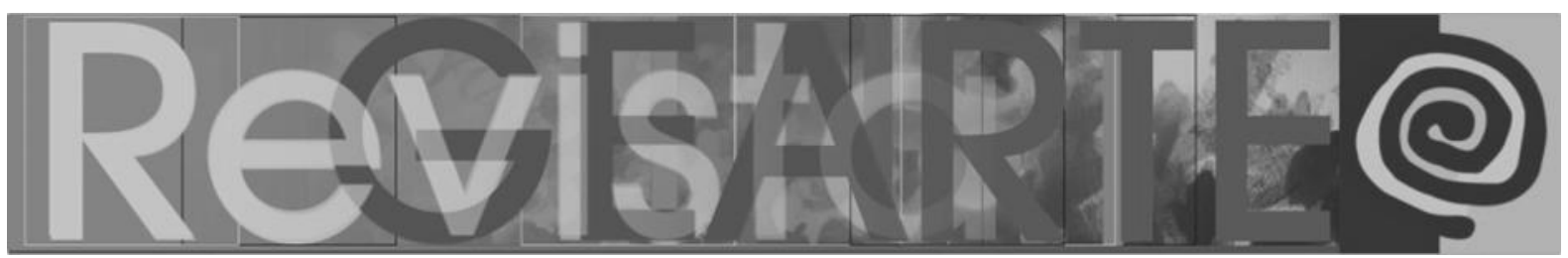

que prossegue o estudo com as visualidades, cujo foco é as artes plásticas. As eletivas e as PPPs em Artes Visuais encerraram matrículas com espera já em sua primeira oferta.

Museus de arte na cidade é outra eletiva que propõe o conhecimento da ação educativa, do acervo e de produções plásticas/tecnológicas/performáticas. Parte das aulas ocorre nas visitas monitoradas aos museus, outra parte na universidade. O deslocamento objetiva também o conhecimento do patrimônio in lócus e a sua trajetória histórica, além de vivências. A aula posterior à visita é de registro, documentação de visualidade da visita. Há uma experiência de troca com os educativos dos diferentes museus e instituições.

Educação Infantil, Infâncias e Arte apresenta as modalidades artísticas, preparando o olhar para as múltiplas linguagens criadas pela criança. Identifica-se o adultocentrismo no controle do desenho e da expressão corporal, empobrecendo sobremaneira a capacidade criativa das crianças e como estas reelaboram os seus simbolismos, transformando as materialidades do espaço.

$\mathrm{Na}$ residência pedagógica, indico caminhos para pensarmos a arte na relação com as necessidades surgidas no âmbito escolar, considerando solicitações do professor de turma e das crianças, além da leitura do Projeto Político Pedagógico valorizando "[...] os princípios de convívio democrático" (GIGLIO; GENTA LUGLI, 2013) e a constituição da identidade profissional. Os residentes elaboram uma ação pedagógica em uma turma que acompanham durante a residência. O meu objetivo é que a arte seja, também, eixo de conhecimento e não um meio. Por este motivo, os estudantes realizam muitos estudos das naturezas dos conhecimentos imbricados em sua ação pedagógica. Após a intervenção pedagógica, ocorre uma reflexão dialética das hipóteses e mudanças futuras na aprendizagem.

O objetivo da RP é possibilitar aprendizagem prática - em situação, ou seja, a partir da realidade, tomando os eventos e aspectos dificultadores da prática pedagógica do professor e da escola como fontes de aprendizado, uma vez que esses aspectos e eventos são tomados como 


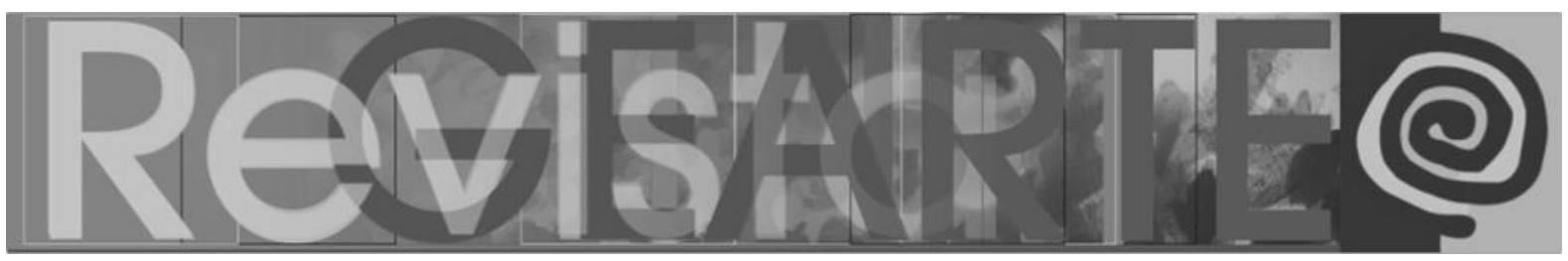

objeto de estudo e reflexão pelos residentes, orientados por seus preceptores e que resultam em matéria a ser tratada também no âmbito da escola, a partir do diálogo com o professor formador e gestores que acolhem o residente na escola. (UNIFESP, 2020, p. 22)

Durante estes anos, tenho realizado formações em artes visuais nas escolas quando solicitada, além da formação na rede. Considero que as redes públicas têm uma grande exigência quanto às provas oficiais, objetivas e verbais, o que impacta na ação dos professores. A categoria aponta para a ausência da arte na formação universitária do pedagogo. Uma parte investe na produção não-verbal pelas crianças e alguns professores, ao aprender a gramática visual das crianças no curso do museu do desenho da criança, relatam mudanças no comportamento destas ao incluir no currículo escolar uma linguagem que é tão necessária à infância.

As Práticas Pedagógicas Programadas são disciplinas ofertadas em cinco encontros durante o semestre para que estudantes conheçam práticas de educação não-formal, realizando estudos não-escolares. A primeira PPP que ofertei no Campus foi o Museu do desenho da criança (em 2011) e, a partir de uma demanda, construí o projeto Museu Virtual do Desenho da Criança, que tratarei adiante. Na sequência, ministrei as PPPs ateliês de arte na cidade, criações lúdicas na arte, HQs e crianças, Museus virtuais de arte, a criança no museu, Labart - entre a educação e a arte (ministrada em parceria com Daniela Finco), e Arte e Educação: o desenho de humor, com visita ao Salão de Humor de Piracicaba. Cada PPP estabelece um estudo com um objeto e/ou fenômeno artístico que apoiará o futuro pedagogo nos diálogos artísticos com as cidades.

Como os artistas pensam a ludicidade no objeto artístico brincante? A primeira brincadeira foi a Arte Postal, conheceram Bicho de Lygia e algumas obras de Cildo Meireles e Palatnik para, finalmente, produzirem um objeto artístico brincante. No dia aberto da Universidade, estudantes da PPP jogaram com os estudantes do ensino médio. 


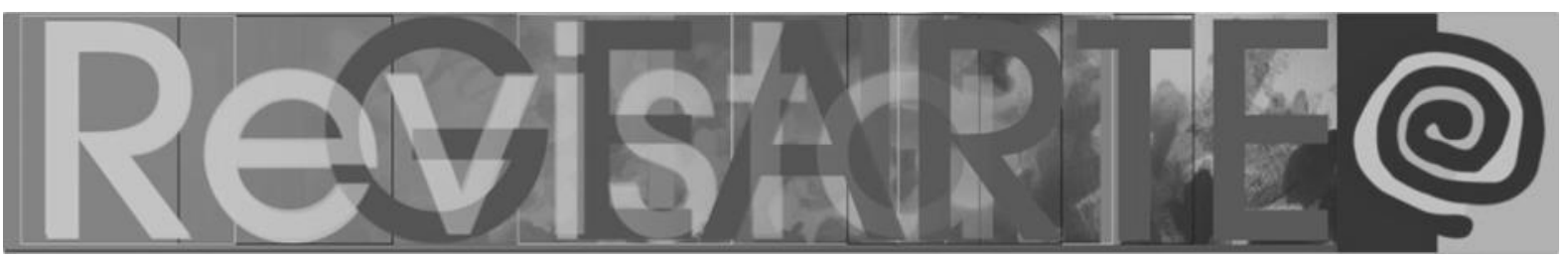

São muitas experiências e, por isso, faço um pequeno recorte com a carta que escrevemos ao PIÁ, o Programa de Iniciação Artística da Prefeitura Municipal de São Paulo. Comparamos o PIÁ e a nossa ida ao equipamento com o haikai, poesia de três linhas, miúda, concisa e que nasce no dia, nas admirações que proporciona a quem se prepara para ver. Estar atento às pequenas surpresas. Olhar com amor. Caminhar, estar atento. Atuar sobre algo na possibilidade de ser inacabado, aberto, um esboço. Capturar o momento fugidio ao desatento e olhar mais:

O que é um haicai? É o passar de um cometa aos olhos do poeta. (BUENO, 2012, p. 17)

É o que acontece agora! Conhecer o pinheiro diretamente no pinheiro. Conhecer a criança diretamente na criança. Ao encontrar os pinheiros (as crianças e as surpresas reconhecidas no dia) o que reativamos em nossas memórias esquecidas pela vida? Os olhos que acompanham os silêncios das crianças às vezes nos abrem portas para mundos desconhecidos. Portas que muitas vezes nos custa ver... Quando não as percebemos perdemos as ocasiões de nos surpreender, de esperar, dar tempo. (FRABBETTI, 2011).

Inspirados nas frases disparadoras da Bienal de Arte Contemporânea, surge a pergunta: qual o caminho que uma ideia percorre? O grupo de crianças traz uma história de encontros e criações. Qual é o desenho construído por essa ideia? Como aconteceram essas elaborações? Certamente não foi do ensinar a fazer, mas sempre há uma intencionalidade nos adultos que mediam e nas crianças que continuam vivências, experimentações e pesquisas.

O Museu Virtual do Desenho da Criança é um projeto que apresentei à rede municipal de Guarulhos em 2011 e que se consolidou em 2015. Nesse projeto, a criança é a interlocutora do desenho e o professor é seu mediador e/ou escriba. São realizados, semestralmente, diversos encontros de formação com os educadores participantes que desenvolvem o projeto junto a seus alunos. Uma síntese desse projeto pode ser apreciada no site museu virtual do desenho infantil. 


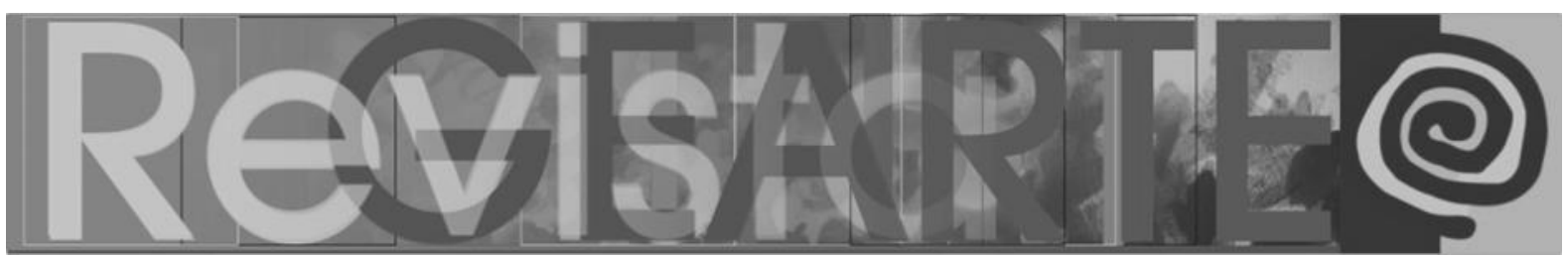

Nesta parte final do artigo, busco resgatar alguns depoimentos ${ }^{6}$ dos(as) estudantes que enriquecem nossa reflexão acerca do significado da disciplina em suas trajetórias. São narrativas que expressam momentos de expectativa, surpresa, criação, mediação, troca, superação... Tudo o que o contato com a arte pode nos propiciar!

Descobri porque eu parei de fazer arte e como isso foi tirado de mim conforme eu crescia.

Imaginava a disciplina de uma maneira menos prática do que foi e isso me deixou com ainda mais vontade de me aproximar das Artes Visuais.

A professora nos provoca para uma reflexão de como fundamentar nossas práticas. Respeita o repertório individual atuando de forma propositiva nesta continuidade, constrói um ambiente saudável para a discussão coletiva. A organização das aulas propiciou a busca do ser poético.

As aulas nos fizeram viver a arte, ficamos em contato com as nossas emoções.

Foi mediadora desse reencontro que tivemos com a arte promovendo situações de significação, demonstrando novas possibilidades e instigando a pensar na educação na perspectiva da arte, promovendo debates e situações de reflexão.

Percebi que as artes são subestimadas na escola. É preciso garanti-la no currículo escolar real.

Formar um ateliê pessoal para as atividades de imaginação onde percebi a vontade de voltar a desenhar, retomei o meu traço perdido, quebrando a minha resistência. Os materiais escolhidos nos levaram para outras leituras de mundo. ${ }^{7}$

\section{Sobre a floresta escura}

Finalizando esta apresentação sobre a disciplina de artes visuais no curso de Pedagogia, observo o longo caminho trilhado e o horizonte que aponta novas terras. Precisamos considerar que ainda não conhecemos as nossas diversas camadas cultivadas e que o espaço educativo poderá orientar o que de fato importa na cultura. O nosso passado camponês dialoga com a nossa atual vida urbana estabelecida desde os anos 1960. Os rastros perdidos de nossa memória ancestral e seus vestígios (rastros memoriais, restos, resíduos e marcas), os pactos de silêncio na selva de pedra, tudo é floresta escura com flores reais. Por isso, 


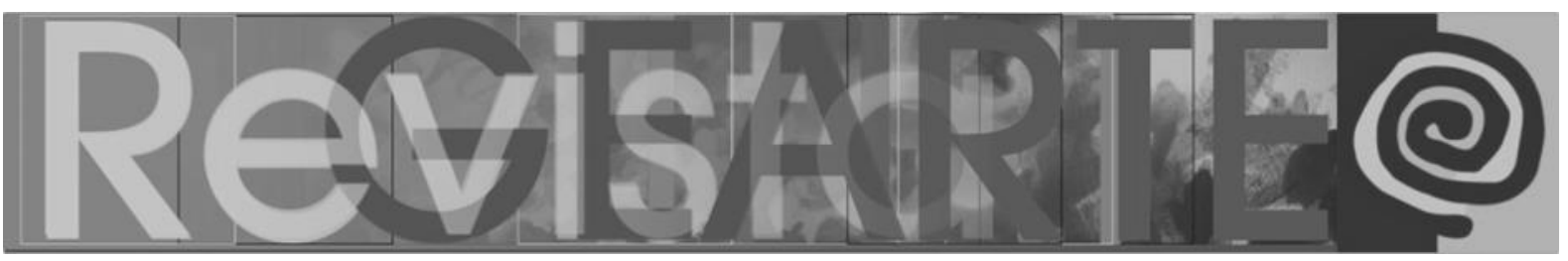

acredito que não entenderemos o fenômeno artístico, uma vez que permanecermos na formalidade do encontro do objeto sem conseguir chegar à imaginação criadora possível, no diálogo com a simbologia do ser e do coletivo.

Cada área possui um conhecimento que não pode ser negligenciado e, quando nos enveredamos a querer contemplar outros conhecimentos, deixamos de fomentar a arte aos estudantes. É preciso ouvir o eco das necessidades contempladas pelo currículo e entender por que a arte deve ser tão presente no curso de pedagogia.

Já que a criatividade é mais importante que o controle, precisamos de ações que abram as janelas da imaginação, mas que, ao mesmo tempo, agreguem conhecimentos intuitivos e racionais. Afetados que somos, segundo André Martins (CRIATIVIDADE, 2017): "[...] precisamos conhecer os afetos que nos mobilizam e aqueles que inibem nossa ação. A criação e o contato com ambientes favoráveis alargam a confiança interna e o nosso potencial criativo."

A arte é formativa, pois expressa uma forma de fazer que invente sua própria linguagem e seus meios. Ela não seria o resultado de um projeto, mas encontraria o resultado no processo de fazer.

A formação dos futuros pedagogos deve apontar para uma mudança de práxis. Isso envolve o clima de sala de aula, uma ambiência para pensamento e comportamento criativos, um ambiente de expressão de ideias, avaliação e metodologia adequadas, interesse pela aprendizagem do aluno provocando o pensamento divergente e o encorajamento. A pressão pela resposta única tolhe 0 pensamento divergente.

Como fruto de preparação, da aprendizagem, de oportunidades e de experiências ricas e diversificadas, a criatividade é cultivada em intenso trabalho, o que pode resultar em inspiração. Discursos manipulam o termo para justificar que é possível fazer milagres em tempos de crise ou que, desde que se tenha 


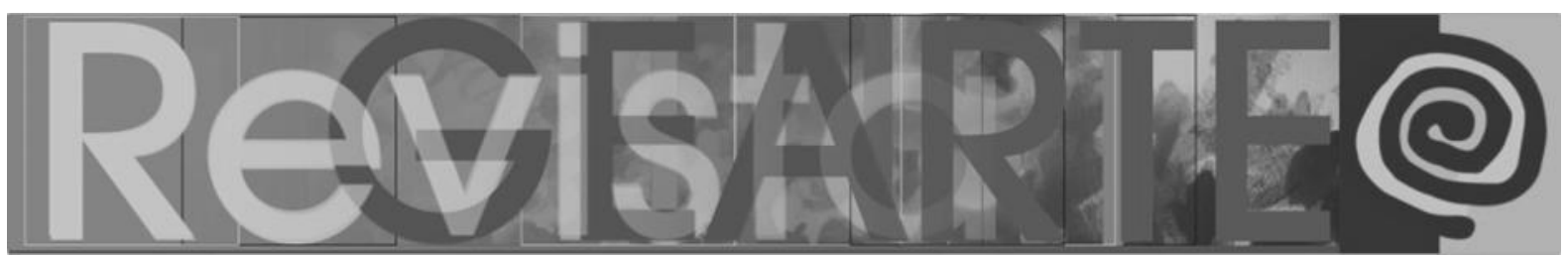

criatividade, instaura-se soluções imediatas. Criatividade não se assemelha à falta de condições materiais, não é um tapa-buraco para a falta de investimento público.

A criatividade deveria ser principal na formação continuada e nas aprendizagens escolares. Temos referências e críticas às provas nacionais de desempenho escolar, contrariamente, apenas em algumas olimpíadas de conhecimento é exigido o pensamento criativo e diferencial. $O$ termo também é aproveitado como salvaguarda da ausência de materiais, com discursos que tentam naturalizar a falta de investimento público, é preciso atentar-se a isso.

É preciso desvendar a vida pelo sensível, pela fantasia e afetividade, renovando e gestando novas qualidades de vida, de forma que a experiência cultural do estudante seja a condição para a arte na educação (PORCHER, 1982).

A coleta e o desenho de observação de folhas retorcidas de outono obrigam a uma maior acuidade visual, mas, antes disso, a uma escolha individual. As imagens do percurso habitam nossos sonhos? Para Bachelard essa atividade ininterrupta instaura novas e sucessivas imagens que nascem de desconstruções aperfeiçoando e afastando o ser das "[...] ilusões primeiras" (BACHELARD, 1998, p. 76). Quando as verdades registradas em nossa memória são negadas e novas ideias são inventadas, houve formação.

\begin{abstract}
O homem quer ver. Ver é uma necessidade direta. A curiosidade dinamiza a mente humana. Mas na própria natureza parece que forças de visão estão ativas. Entre a natureza contemplada e a natureza contemplativa, as relações são estreitas e recíprocas. A natureza imaginária realiza a unidade da natura naturans e da natura naturata. Quando um poeta vive seu sonho e suas criações poéticas, ele realiza essa unidade natural. Parece então que a natureza contemplada ajuda à contemplação, que ela já contém meios de contemplação... Ele diz ao querer: não irás mais longe; tens o dever de contemplar as coisas distantes, coisas além! (BACHELARD, 1998, p. 76)
\end{abstract}

A experiência dos estudantes de Pedagogia com as artes visuais poderia ser sintetizada na forma de uma espiral poética, expressão que reflete o dinamismo que articula a razão intuitiva, a imaginação criadora e a intersubjetividade elementos indispensáveis aos saberes e fazeres da arte. 


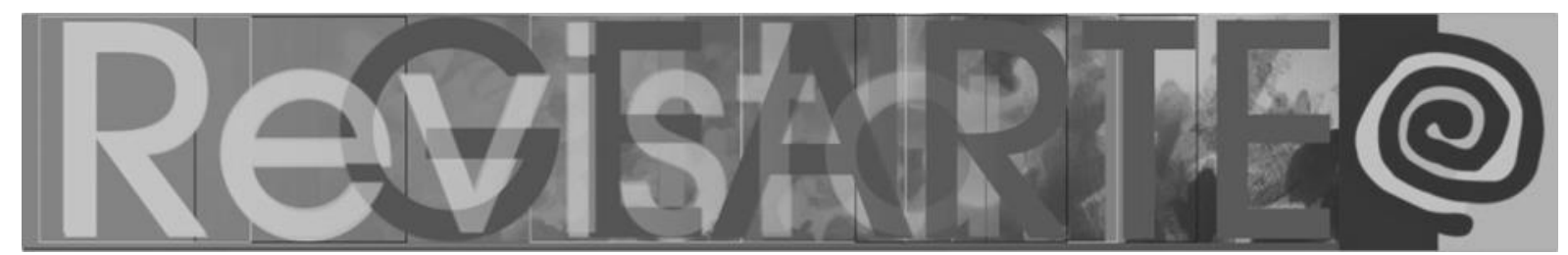

\section{Notas}

1 Bachelard (1998, p. 27).

2 Já a residência pedagógica criada em 2016 pelo governo federal, apesar de termo homônimo, é um programa de natureza distinta.

3 Para o grupo Graffiteratura a fonte de inspiração do projeto é a literatura interpretada graficamente pelos artistas como intervenção urbana. Em 2016 os artistas Grego, Beto Silva e Frenesi grafitaram a obra no campus Guarulhos. O mural é inspirado no Auto da Barca do Inferno de Gil Vicente e no movimento da história da arte: o muralismo mexicano. Foi vencedora no edital de revitalização do Campus da EFLCH/UNIFESP.

4 Nasceu após a escola russa Vkhutemas sendo por ela influenciada.

5 O espaço do desenho: a educação do educador de Ana Angelica Albano é uma das obras que inspiram a escrita do memorial de artes. Dá continuidade à escrita sensível da memória, estabelece o desenho como linguagem da criança ao passo que repensa esse espaço-tempo escolar para a recuperação do ser poético.

6 Avaliação escrita.

7 Depoimentos, registros em aulas e avaliações anônimas de alunos das PPP.

\section{Referências}

ALBANO, Ana Angélica. O espaço do desenho: a educação do educador. São Paulo: Edições Loyola, 2008.

ARNHEIM, Rudolf. Arte e percepção visual: uma psicologia da visão criadora. São Paulo: Thomson Learning, 2006.

AUSUBEL, David P., NOVAK, Joseph D., HANESIAN, Helen. Psicologia educacional. Tradução Eva Nick. Rio de Janeiro: Interamericana, 1980.

BACHELARD, Gaston. $A$ água e os sonhos: ensaio sobre a imaginação da matéria. São Paulo: Martins Fontes, 1998.

BARBOSA, Elyana; BULCÃO, Marly. Bachelard: Pedagogia da razão pedagogia da imaginação. Petrópolis, Vozes, 2004.

BOSI, Alfredo. O ser e o tempo da poesia. São Paulo: Companhia das Letras, 2000.

BOSI, Ecléa. Memória e sociedade. São Paulo: Companhia das Letras, 1994.

BUENO, Carlos Alberto. Raiar Poemas Haicai. São Paulo: Ed. All Print, 2012.

CRIATIVIDADE transformadora: expressão de uma força vital, com André Martins. Direção de Marta Maia. Produção de TV Cultura. Campinas: Instituto CPFL, 2017. Disponível em: $<$ https://institutocpfl.org.br/criatividade-transformadora-expressao-de-uma-forca-vital-com-andremartins/>. Acesso em jul 2021.

EDWARDS, Betty. Desenhando com o lado direito do cérebro. São Paulo: Ediouro, 1984.

FRABBETTI, Roberto. A arte na formação de professores de crianças de todas as idades: o teatro é um conto vivo. Pro-Posições, Campinas, v. 22, n. 2 (65), p. 39-50, maio/ago. 2011.

GARAUDY, Roger. Karl Marx. Rio de Janeiro, Ed. Zahar, 1967.

GIGLIO, Célia Maria Benedicto; GENTA LUGLI, Rosário Silvana. Diálogos pertinentes na formação inicial e continuada de professores e gestores escolares. A concepção do Programa de Residência 


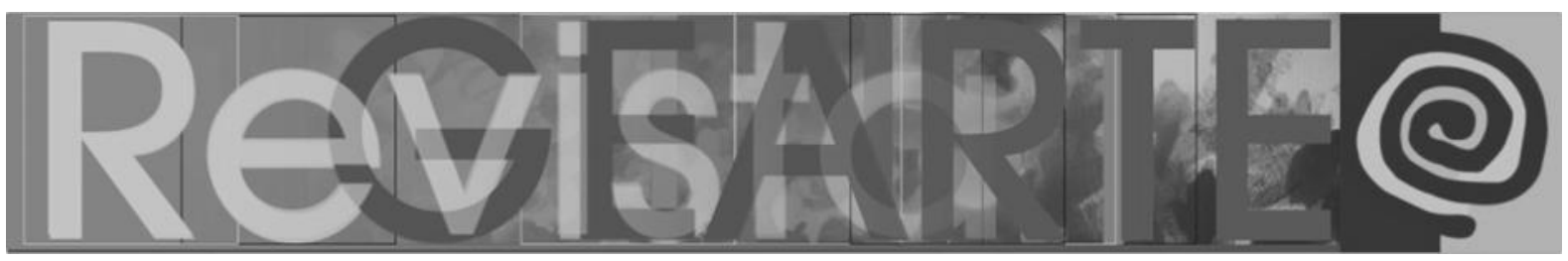

Pedagógica na UNIFESP. Cadernos de Educação, n. 46, 2013. Disponível em: https://periodicos.ufpel.edu.br/ojs2/index.php/caduc/article/view/4173. Acesso em: 15 abr. 2020.

LIBANIO, João Batista. Mobilizações concretas na cidade. In: LIBANIO, João Batista. As lógicas da cidade. São Paulo: Ed. Loyola, 2002.

MARX, Karl. Manuscritos Econômicos e Filosóficos. São Paulo: BoiTempo Editorial, 2004.

OLIVEIRA, Leni Marcia Curcio de. A importância do Ensino de Artes Visuais na formação de professores. 50f. Trabalho de Conclusão de Curso (Graduação em Pedagogia). Escola de Filosofia, Letras e Ciências Humanas, Universidade Federal de São Paulo. Guarulhos, 2019.

PORCHER, Louis. Educação Artística: luxo ou necessidade? São Paulo: Summus, 1982.

TAVARES, Monica. Inter-relações entre arte, pesquisa e ciência. Diálogos transdisciplinares; arte e pesquisa. Gilbertto Prado, Monica Tavares, Priscila Arantes (organizadores) - São Paulo : ECA/USP, 2016. 500 p.

UNIFESP. Projeto pedagógico do curso de pedagogia. Guarulhos, 2020. Disponível em: https://www.unifesp.br/campus/gua/images/Apoio_Pedagogico/Projetos_Pedagogicos/2020_PPC _PEDAGOGIA_2020_vfinal_atualizado.pdf. Acesso em: 15 abr. 2020

VYGOTSKY, Lev Semenovitch. Imaginação e criatividade na infância. São Paulo: Martins Fontes, 2014.

VILLAS BOAS, Benigna Maria de Freitas. Portfólio, avaliação e trabalho pedagógico. Campinas: Papirus, 2004.

ZAMBONI, Silvio. Pesquisa em arte: um paralelo entre arte e ciência. Campinas, SP: Autores Associados, 2012.

\section{Betania Libanio Dantas de Araujo}

Professora do Departamento de Educação da Universidade Federal de São Paulo. Graduada em Artes Plásticas pela Faculdade de Belas Artes de São Paulo. Mestre em Artes Visuais pela Universidade Estadual Paulista. Doutora em Educação pela Universidade de São Paulo.

ORCID: https://orcid.org/0000-0001-7943-2786

E-mail: betaniadantas@hotmail.com

Currículo: http://lattes.cnpq.br/3104010388590983

Recebido em 22 de fevereiro de 2021

Aceito em 30 de abril de 2021 